\title{
Recent advances in testing and field investigations on stability of flyash as back filling material in opencast mines
}

\author{
Singam Jayanthu \\ Department of Mining Engineering \\ National Institute of Technology-Rourkela, \\ Rourkela, India \\ sjayanthu@nitrkl.ac.in
}

\begin{abstract}
This paper presents the results of laboratory investigation, field geotechnical investigations and numerical analysis for understanding the stability of overburden Material including Fly ash in Jindal power opencast coal Mine, India. Numerical models were used for estimation of stability of the back filling material with varying geometry of layers of fly ash and overburden. It is observed that two types of dumps with alternative layer of only fly ash and overburden material, and overburden mixed with fly ash $(25 \%)$ are found to be stable with safety factor more than 1.2. Geometry of the stable dump has total height of $120 \mathrm{~m}, 4$ number of decks, individual deck height of $30 \mathrm{~m}$, and slope of each deck as $32^{\circ}$.
\end{abstract}

The dump formed with alternate layer of overburden and mixture of fly ash is found stable with a safety factor of 1.78 for the above geometry. Therefore, the above geometry of the back filling material was recommended for the above mine and field trials were successfully conducted for the first time in India. As a part of reclamation with plantation, top soil of nearly $2 \mathrm{~m}$ thick was spread over the dump material in the field. Displacement pattern of the monitoring stations during 2012 to 2014 indicated no significant displacement in the Overburden dumps with fly ash ensuring stability of the dump.

Keywords-dump, fly Ash, numerical model, opencast coal mine, slope stability, field investigations, testing

\section{INTRODUCTION}

Fly ash generation and utilisation scenario indicates urgent need of efforts from concerned agencies for reducing the gap of about 110 Million tones of Fly ash (FA) during 2011-12, and conducting need based research for innovative measures in proper utilisation of the Fly ash shown in Table I. Although meticulous attempts are being made by CFARM-New Delhi under the Dept of Science and Technology, many more studies are required for ecofriendly application in mass utilisation of FA. Jindal Power Open Cast Coal Mine is captive mine of Jindal's $1000 \mathrm{MW}$ (4 x $250 \mathrm{MW})$ thermal power plant. The block is located

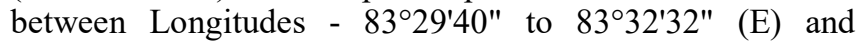
Latitude - $22^{\circ} 09^{\prime} 15^{\prime \prime}$ to $22^{\circ} 05^{\prime} 44^{\prime \prime}(\mathrm{N})$ falling in the topo sheet number 64 N/12 (Survey of India). Administratively, the block is under Tamnar Tahsil of Raigarh District, Chhattisgarh. The block is well connected by Road. It is about $60 \mathrm{~km}$ from Raigarh town, which is district head quarter and nearest railway station on Mumbai - Howrah Main Line. Management of Jindal power opencast coal Mine-Tamnar, Raigarh, proposed to conduct scientific studies for the assessment of overburden dump slope stability using fly ash. However, its utilization is nearly $50 \%$ of the production (2009-10), which is very less in comparison to the major fly ash producing countries like China, U.S.A. and Germany [1]. Table I shows the amount of fly ash generated at utilized in India.

As part of the studies, NIT-Rourkela conducted field investigations, and laboratory studies were carried out at Geotechnical Laboratory of NIT-Rourkela. National Thermal Power Corporation used about 60,000 tons of ash for backfilling underground mines of Singareni Colliery

TABLE I. GENERATION AND UTILISATION OF FLY ASH IN INDIA

\begin{tabular}{|l|l|l|}
\hline Year & $\begin{array}{l}\text { FA generation } \\
\text { (Million Tonne) }\end{array}$ & $\begin{array}{l}\text { FA utilization (Million } \\
\text { Tonne) }\end{array}$ \\
\hline $\mathbf{1 9 9 4}$ & 40 & 1 \\
\hline $\mathbf{2 0 0 8}$ & 160 & 80 \\
\hline $\mathbf{2 0 1 1 - 2 0 1 2}$ & 220 & 110 \\
\hline $\mathbf{2 0 3 1 - 2 0 3 2}$ & 1000 & -- \\
\hline
\end{tabular}

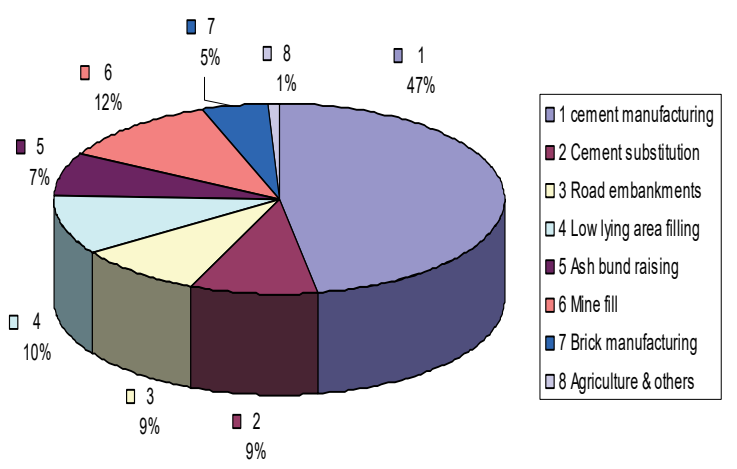

Fig. 1. Utilisation of fly ash in various sectors during 2012 in India

Company Limited, Southern India during 1999 [2]. There is also a report of mine back filling using fly ash at Singrauli and Damoda opencast mines in India $[3,4]$. 
Based on the various physico-mechanical properties and the field studies, empirical models and numerical modeling studies were conducted for the stability of dump slope. The main objective of the study was to determine stability of overburden dump formed by the utilization of fly ash. During 2012, low percentage of the Fly ash was used for mine fill purpose, and mass utilisation can be expected by proper use as back fill in open cast mines, such as the case study at JPL mine, conducted with initial laboratory tests on the fly ash generated at JPL-Tamnar power plant and its admixture with $\mathrm{OB}$, design of dump geometry, filed application and field monitoring for more than three years for the first time in India as shown in Fig. 1 [8].

\section{Geomining COndition- CASE Study at JPL Mines}

In general, area of the coal block - Jindal Power Open Cast Coal Mine is almost flat with small undulations from surface. The lithological section comprises about 3-4 m unconsolidated loose soil/alluvium. Below the top soil there is weathered shale/sandstone up to $6-8 \mathrm{~m}$ depth. The weathered shale and sandstone are comparatively loose in nature and can be excavated without blasting. Below weathered zone (which varies from $3-10 \mathrm{~m}$ ), the rock is hard, compact and massive in nature and can be excavated only after blasting. Thus the average depth of the excavation of these excavations, which can be removed, is about $16 \mathrm{~m}$. In the sub-block IV $/ 2 \&$ IV $/ 3$ only lower groups of Gondwana sediments have been deposited. Strata are gently dipping by 2 to $5^{\circ}$ southwesterly. The general strike of the sediments is in NW-SE, and almost uniform throughout the block. Two normal faults of small magnitude have been deciphered based on the level difference of the floor of the seams, though the presence of some minor faults of less than $5 \mathrm{~m}$ throw cannot be overruled [7].

The Mand Raigarh basin is a part of IB River - Mand Korba master basin lying within the Mahanadi graben. The sub-block IV/2 \& IV/3 of Gare-Pelma area is structurally undisturbed except one small fault (throw 0-15 m) trending NE-SW with westerly throws. The strike of the bed is NW$\mathrm{SE}$ in general with dip varies from $2^{\circ}$ to $6^{\circ}$ southwesterly. The strata shows rolling dip. In the sub block IV/2 \& IV/3 total 10 number of persistent coal seams have been established. They are seam X to I in descending order. Seam I is impersistent due to metamorphism in the central and eastern part of the block. Depth of mine working is about 36 $\mathrm{m}$ with six benches of $6 \mathrm{~m}$ height. Ultimate depth of the mine would be about $120 \mathrm{~m}$ from RL of 271 to $151 \mathrm{~m}$. Back hoe in combination of dumper with $6 \mathrm{~m}$ bench height is adopted for excavation in the mine. It is also proposed to have $6 \mathrm{~m}$ height benches at the time of formation of ultimate pit slope.

\section{Methodology For DuMPING OF Fly Ash}

It was proposed earlier to have internal overburden dumps of maximum height of $30 \mathrm{~m}$ in each individual deck with four decks up to $120 \mathrm{~m}$ overall dump height. Presently overburden dump height is about $72 \mathrm{~m}$ with a maximum deck height up to $25 \mathrm{~m}$ in this mine. These dumps and slopes are observed to be stable at present. Stability analyses for the proposed dumps were undertaken using various techniques for the maximum dump height of $120 \mathrm{~m}$, which is the ultimate depth of the mine. Ground Water level conditions are below the $13 \mathrm{~m}$ from the surface and benches are generally dry. Table II shows the bench parameters being followed at present.

Mine plan and the view for the dumping of fly ash at Jindal Power Open Cast Coal Mine; Tamnar is shown in Fig. 2 and 3, respectively. Initially a row of overburden was dumped forming an embankment with a width of greater than $15 \mathrm{~m}$ and height up to $5 \mathrm{~m}$ all around the proposed area for fly ash dump.

TABle iI. Bench Parameters Being Followed at Present

\begin{tabular}{|l|l|}
\hline Bench Parameter & Followed at the distance presently \\
\hline Bench height & $6 \mathrm{~m}$ \\
\hline Numbers of working benches & 6 \\
\hline Width of the bench & $20 \mathrm{~m}$ \\
\hline Gradient of the ramp & 1 in 16 \\
\hline
\end{tabular}

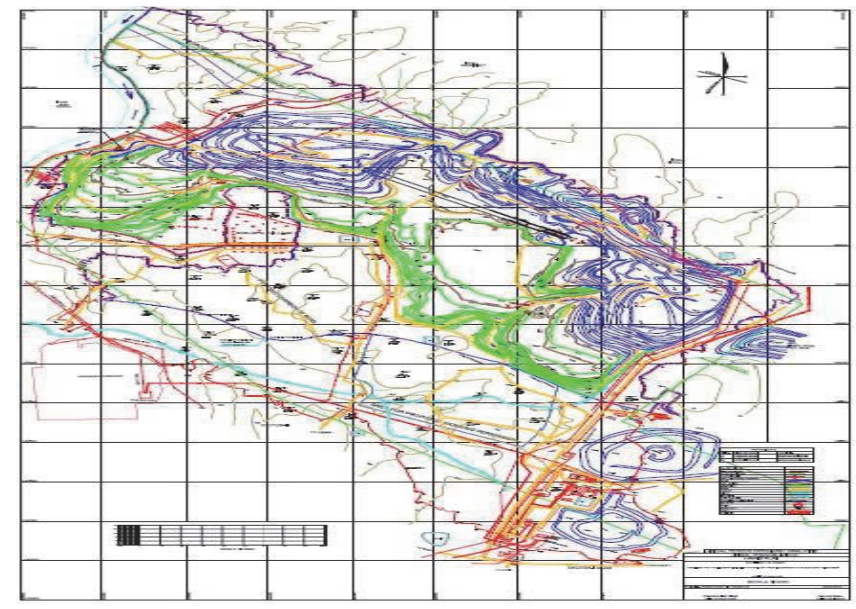

Fig. 2. Utilisation Location of study site at JPL mines, Tamnar

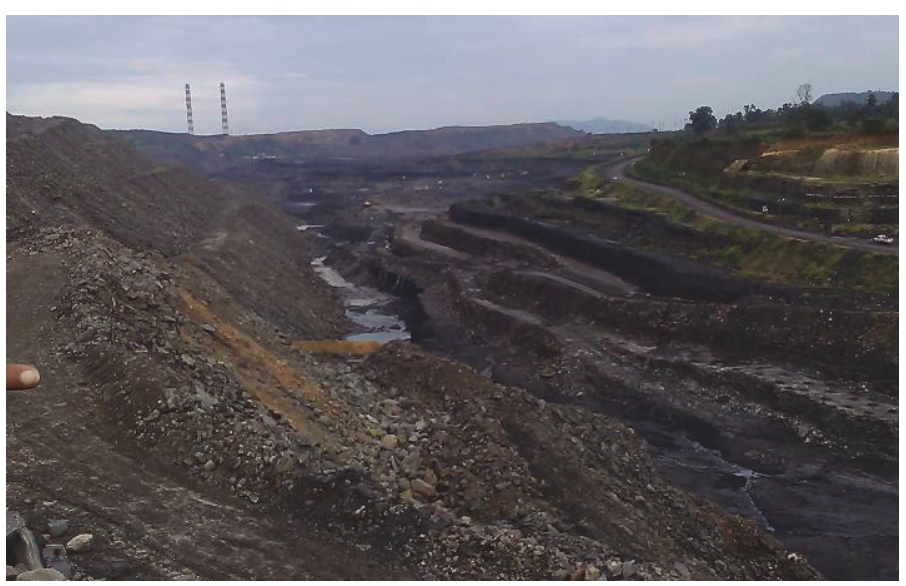

Fig. 3. A view of fly ash overburden admixture at dump site and working mine benches at JPL mines

A number of such areas were formed in a layer wherein the fly ash was dumped so that each dump of fly ash was separated by another overburden dump of $15 \mathrm{~m}$ wide in 
order to control the airborne quality of the fly ash. Fly ash was dumped within this area surrounded by overburden in alternate layers of height not exceeding $5 \mathrm{~m}$ in each layer. Therefore, each layer of overburden was followed by a layer of mixture of fly ash and overburden (fly ash 25\%) and so on up to the height of $30 \mathrm{~m}$. Fig. 4 and 5 shows photograph of fly ash and OB in the overburden dump with ash pond and close view, respectively. The side of the overburden dump is benched and the angle of slope is about $32^{\circ}$. Dump is compacted; width of the dump is about $40 \mathrm{~m}$ and the overall slope is about $27^{\circ}$ from the horizontal. The toe of the dump is protected by putting the compact rocks (Overburden material) in order to restrict the possibility of any failure in future. Fig. 6 shows decks with Fly ash as admixture in overburden material after compaction.

Jindal Power Limited, Tamnar has already have captive thermal power plants of $1000 \mathrm{MW}$ and generating fly ash, a solid coal combustion residue form due to the burning of coal, of nearly 16000 tons per day. Therefore, quantity of fly ash generated requires large area for its dumping. In last two decades it was realized that fly ash is no more a waste. Its utilization has increased by several folds, and particularly in

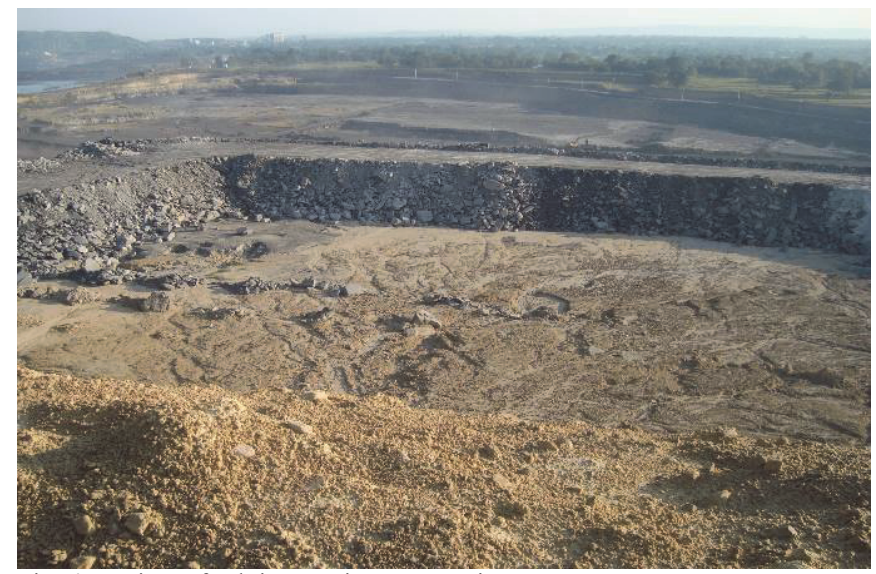

Fig. 4. A view of ash in OB site at JPL mines

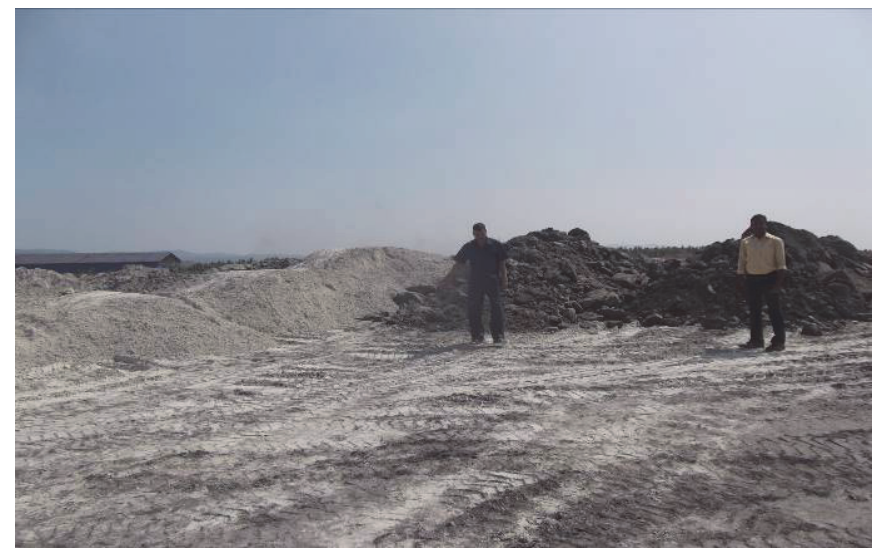

Fig. 5. Close view of fly ash heaps and overburden material at dump site

mining industries. Fly ash is being used at JPL along with overburden material for backfilling in the mine as per the DGMS guide line. Mixing overburden with fly ash improves the mechanical strength of dump as fly ash absorbs the moisture from clay as well as substantially increases the strength of the resultant mixture due to the pozzolanic properties of ash [5].

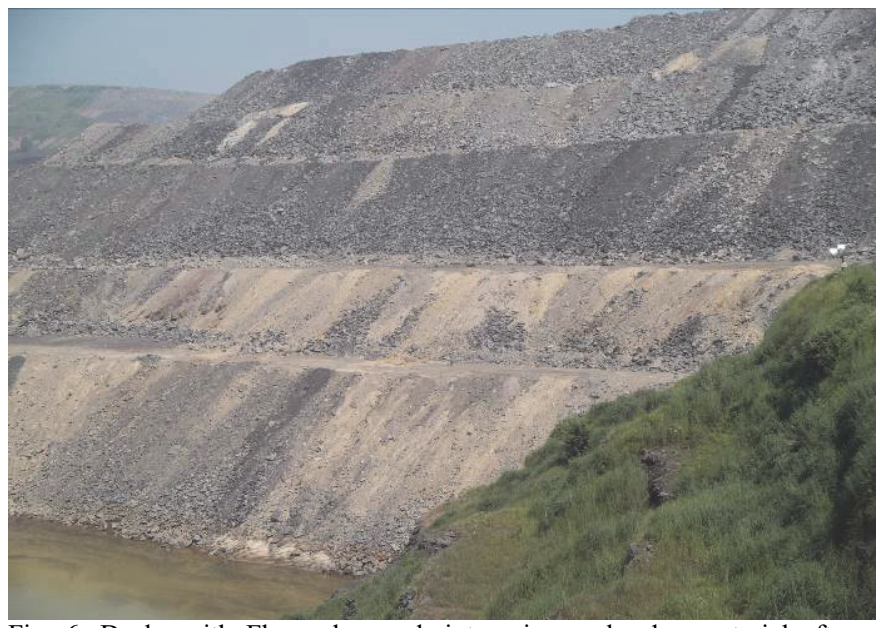

Fig. 6. Decks with Fly ash as admixture in overburden material after compaction

\section{PhYSIO-MECHANICAL PROPERTIES OF ADMIXTURE OF FLY ASH AND OB}

Physio-mechanical properties (Uniaxial Compressive Strength and Density), of the Bore hole \# 32 and 44 indicating that the strata overlying seam IX consists of Alternative bands of fine grained sandstone and shale with compressive strength of about $14 \mathrm{MPa}$. Density of the coal in the seams IX, VIII, VII are in the range of 1.34-1.43, 1.41-1.63, and 1.57-1.67 g/cc respectively. Shear Strength Parameters; Cohesion, $\mathrm{C} \mathrm{t} / \mathrm{m}^{2}$, and Angle of internal friction $\Phi$ are in the range of 0.2 to 0.7 and 35 to 38 degrees , respectively. Various samples of overburden, soil and fly ash from the dump site were supplied by the Jindal Power Limited for finding out various geotechnical properties through the laboratory study. Different geotechnical tests were conducted for the overburden and the fly ash samples collected from the site. Laboratory geotechnical investigation was carried out for determination of grain size distribution, specific gravity, compaction characteristics (optimum moisture content and maximum dry density), and shear strength characteristics following Bureau of Indian standard (BIS) methods. The parameters like density, and shear parameters cohesion $(C)$ and angle of internal friction (angle of repose) are determined for both overburden and fly ash to analyze stability of dumped slope. The typical grain size distribution of the overburden and fly ash is shown in Fig. 7. The particle size of the overburden ranges between gravel, sand and silt. However, the grain size distribution of fly ash and most of the fly ash corresponds to the silt size. The specific gravity of the fly ash found to be very low (average value of 2.15) in comparison to specific gravity of over burden as 2.79. This low specific gravity of fly ash reduces the total weight of the dumped slope and may help in increasing the stability of the dumped slope. 
The laboratory compaction characteristics of the fly ash are shown in Fig. 8, and it was observed that the optimum moisture content (OMC) was found to be $22.9 \%$ and maximum dry density (MDD) as $1.27 \mathrm{gm} / \mathrm{cc}$. The MDD of the overburden is $1.87 \mathrm{gm} / \mathrm{cc}$ and $\mathrm{OMC}$ is $11.4 \%$. It was observed that the OMC is $12.85 \%$ and MDD found to 1.74 $\mathrm{gm} / \mathrm{cc}$ for the mixture. This reduction in MDD is due to low MDD of fly ash. One-way this also helps in reducing the self-weight (driving force) of the slope. The shear strength characteristics of the overburden and mixture of fly ash with overburden are shown in Table III. These properties are used for the stability analysis of dumped slope.

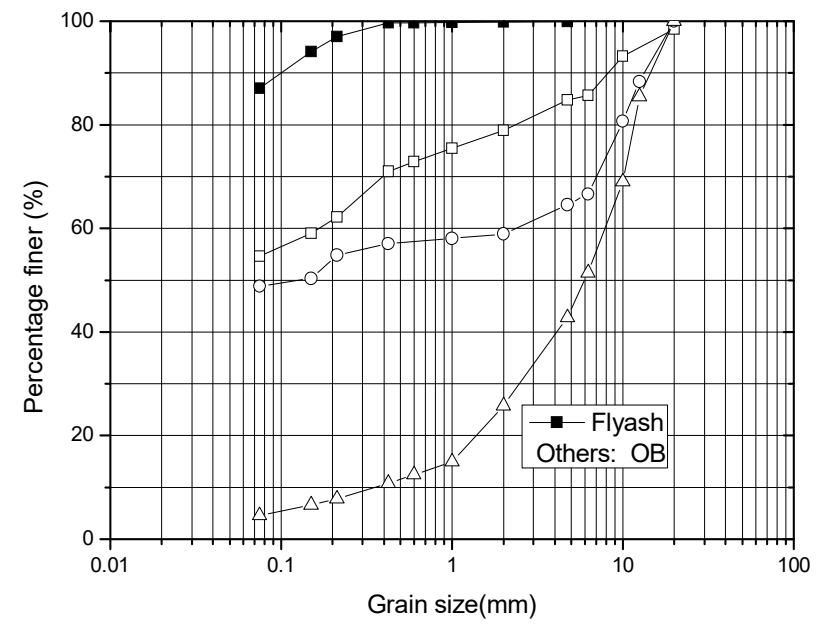

Fig. 7. Grain size distribution of typical overburden (OB) and fly ash

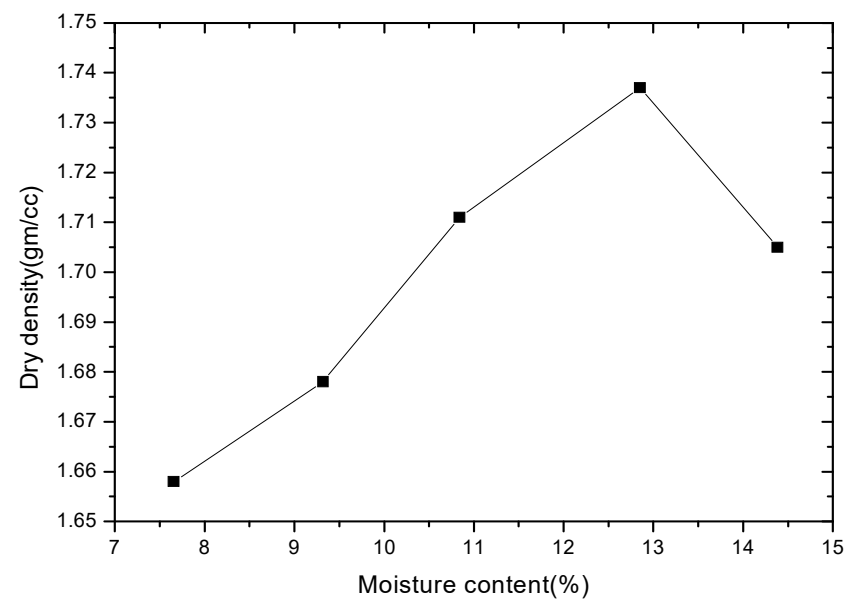

Fig. 8. Compaction characteristics of mixture of overburden and fly ash (25\%)

TABLE III. SHEAR PARAMETERS FOR THE OVERBURDEN, SOIL AND MIXTURE OF FLY ASH AND OB

\begin{tabular}{|l|l|l|}
\hline Sample type & Cohesion $\left(\mathbf{k N} / \mathbf{m}^{2}\right)$ & $\begin{array}{l}\text { Angle of internal } \\
\text { friction(}(\boldsymbol{\Phi}), \text { Degree }\end{array}$ \\
\hline Overburden & 41.8 & 28.5 \\
\hline Fly ash + OB & 89.6 & 22.9 \\
\hline Soil & 78.2 & 20.5 \\
\hline
\end{tabular}

\section{SLOPE STABILITY ANALYSIS}

The stability of dumped slope is analyzed by PLAXIS software, Version 9 using the above geotechnical parameters. PLAXIS is a finite element program for geotechnical applications in which Mohr- Coloumb models are used to simulate the behavior of dump material. Its implementation consists of three stages, known as input stage, calculation stage and post processing (curves) stage. Input stage contains model design, assigning the material parameters, boundary conditions, loading and meshing. In the present analysis 15-node triangular element is considered for meshing which contains 12 stress points. In PLAXIS, stresses and strains are calculated at individual Gaussian integration points rather than at nodes. In the calculation stage, analysis type is chosen such as Plastic, dynamic, consolidation and phi-c reduction. The assigned loads are activated in this stage and analyzed. In the post processing stage, curves are plotted between various calculated parameters such as load Vs displacement. In PLAXIS Phi-c reduction method is used to compute factor of safety (FOS) for dump slope stability. The total multiplier $\Sigma M s f$ (Eqn. 1) is used to define the value of the dump material strength parameters at a given stage in the analysis.

$$
\sum \mathrm{Msf}=\frac{\tan \Phi}{\tan \Phi_{r}}=\frac{c}{c_{r}}
$$

The safety factor is then defined as the value of $\sum \mathrm{M}_{\mathrm{sf}}$ at failure, provided that at failure more or less constant value is obtained for a number of successive load steps. Different trials were made with overburden and mixture of overburden and fly ash with overall slope angle of $27^{\circ}$. Here two trials are presented.

This trial-1 was made with the overburden and mixture of over burden with $25 \%$ fly ash. The results are shown in Fig. 9. The Factor of Safety obtained was 1.75 , and as it is much higher than 1.2. This overburden does satisfy the minimum requirement and can be used along with the fly ash.

This trial- 2 was made for the dump prepared by alternate layer of overburden and mixture of overburden and $25 \%$ fly ash along with the incorporation of top soil of nearly $2 \mathrm{~m}$ thickness at the top of the dump for the reclamation purpose. The Factor of Safety obtained was 1.78 , and as it is more than 1.2. This indicates that at the end the dump after dozing of top soil, the dump satisfies the minimum requirement and can be used. However, top soil should be protected against rainfall by taking measures like plantation, geosynthetics, or jute/coir reinforcement.

The compaction control may be periodically checked for proper compaction of overburden and fly ash mixture. Slope stability of the overburden dump after mixing of fly ash, it was observed that on the application of $25 \%$ fly ash mixture safety factor has increased to 1.78 , which was only 1.32 with $8 \%$ fly ash mixture with overburden. This increase may 


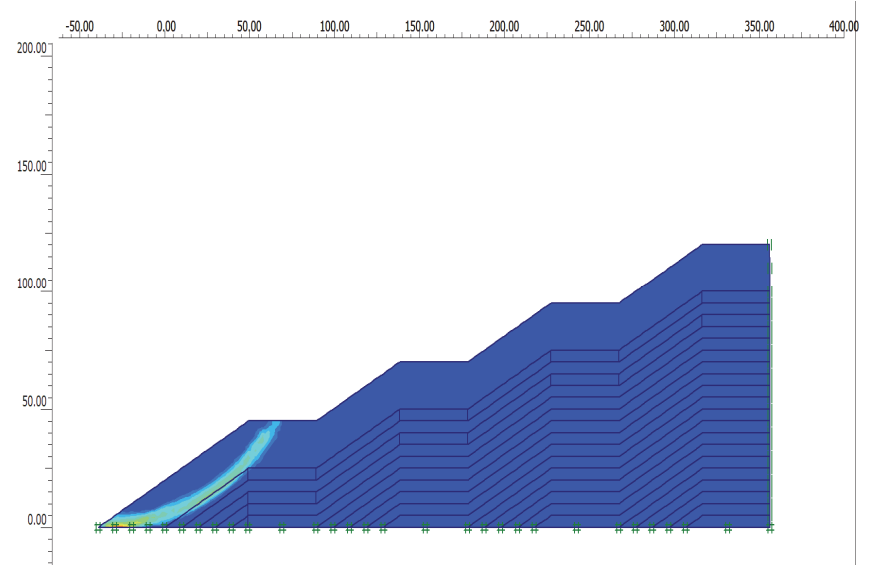

Fig. 9. Failure surface with factor of safety 1.75 as per PLAXIS analysis for Trial 1

be attributed to the increase in cohesion of the mixture due to self-cementing properties of fly ash generated from the combustion of sub-bituminous coal. In presence of water, the fly ash will harden and get strength over time. Fig. 10 shows a view of the plantation duirnginitia days on the overburden dump form by utilizing fly ash at Jindal Power Limited, Tamnar.

\section{Slope Stability Monitoring}

As per the DGMS permission for fly ash filling in opencast working along with overburden, height of dump was limited to $30 \mathrm{~m}$. The height of dump at study site was about $25 \mathrm{~m}$. Final stage dump consist of $2 \mathrm{~m}$ top soil above the layers of $\mathrm{OB}$ and $\mathrm{OB}$ mixed fly ash material. Stability of Dump slopes was monitored with total station and monitoring stations fixed at an interval of 20 to $30 \mathrm{~m}$ on the dumps at a distance of about $5 \mathrm{~m}$ from the crest of the dump slope (Singam Jayanthu, and Simantini Behera, 2013). 47 monitoring stations were installed with $1.0 \mathrm{~m}$ long pipes and masonry pillars; 23 stations in the Pit 1 and 24 stations in Pit 2 and total station was used for measuring RL of the stations as shown in Fig. 11.

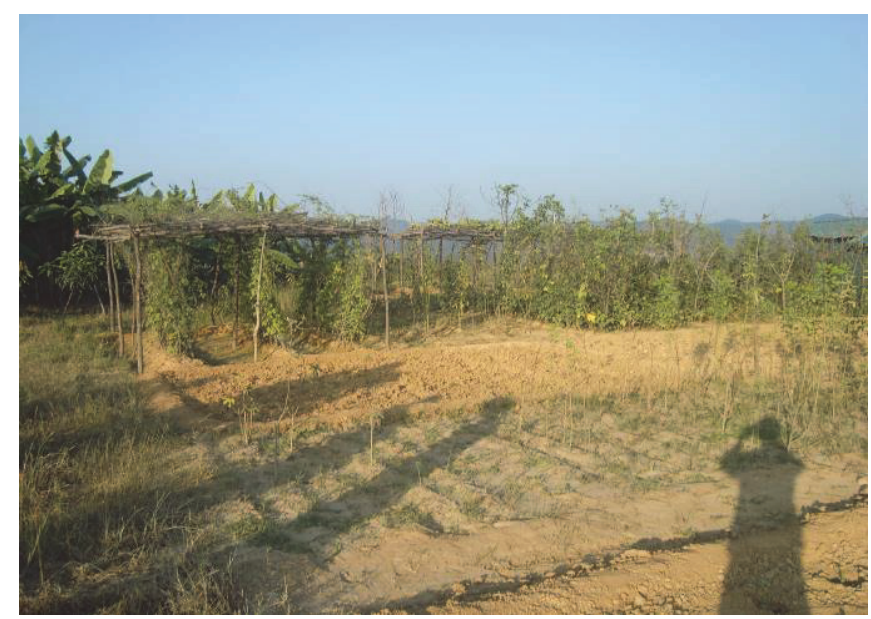

Fig.10. A view of the plantation over the admixture of OB and Fly ash at Jindal Power Limited, Tamnar

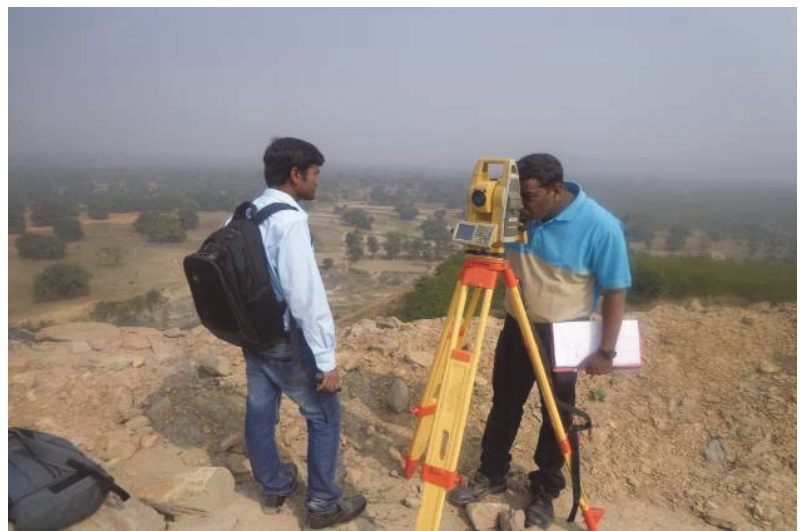

Fig.11. Total station for measuring Reduced Levels of monitoring stations

reduced levels of monitoring stations during nov'12 to the end of march'13 indicated maximum vertical displacement of $-0.018 \mathrm{~m}$ was noticed in pit 1 , while the vertical displacement was limited to $-0.01 \mathrm{~m}$ in pit 2 [8]. negative displacement may be considered as settlement of the material over time. the analysis of the rls of the monitoring stations in pit- 1 and pit-2, indicates that more than $50 \%$ of the stations showed no further displacement. monitoring station kjs2 was disturbed due to movement of the machinery. few stations showed no trend in vertical deformation as they showed downward as well as upward

Table IV. Status of Vertical Displacement of Dump at the MONITORING STATIONS

\begin{tabular}{|c|c|c|c|c|c|}
\hline \multicolumn{2}{|c|}{ Zero displacement } & \multicolumn{2}{|c|}{$\begin{array}{l}\text { Downward } \\
\text { displacement }\end{array}$} & \multicolumn{2}{|c|}{$\begin{array}{l}\text { Haphazard } \\
\text { displacement }\end{array}$} \\
\hline Pit-1 & Pit-2 & Pit-1 & Pit-2 & Pit-1 & Pit-2 \\
\hline $\begin{array}{l}\text { AS1, AS } \\
2, \text { AS } 3, \\
\text { AS } 12, \\
\text { AS } \\
13, \text { AS } 14, \\
\text { AS } 15, \\
\text { A16, AS } \\
18, \text { AS } 19, \\
\text { AS 20, } \\
\text { AS21 }\end{array}$ & $\begin{array}{l}\text { KJS6, KJS } \\
7 \text {, KJS } 8, \\
\text { KJS 9, KJS } \\
10, \text { KJS 13, } \\
\text { KJS 14, } \\
\text { KJS 15, } \\
\text { KJS 16, } \\
\text { KJS } 17, \\
\text { KJS } 18, \\
\text { KJS 20, } \\
\text { KJS } 22\end{array}$ & $\begin{array}{l}\text { AS4, AS } \\
6, \\
\text { AS } 7, \\
\text { AS 9, AS } \\
10, \text { AS } \\
17, \text { AS } \\
22, \text { AS } \\
23\end{array}$ & $\begin{array}{l}\text { KJS } 1, \\
\text { KJS } 4, \\
\text { KJS } 11, \\
\text { KJS } 12, \\
\text { KJS } 19, \\
\text { KJS } 23 \text {, } \\
\text { KJS } 24\end{array}$ & $\begin{array}{l}\text { AS 5, } \\
\text { AS 8, } \\
\text { AS } 11\end{array}$ & $\begin{array}{l}\text { KJS3 } \\
\text {, KJS } \\
5\end{array}$ \\
\hline
\end{tabular}

vertical displacement from Nov.2012 to the end of March 2013 shown in Table IV. This irregular deformation pattern may be due to differential settlement and consolidation of the material near the monitoring stations. Incremental downward vertical displacement of about $30 \%$ of the monitoring stations indicates gradual settlement of the material, which may settle further in due course of time. It does not show any accelerating trends in deformation which is one of the indicators of slope failure. It necessitates further study of these stations till total settlement occurs. As the dump was formed only a year back, it may be inferred that settlement of the dump material at some places may take more than a year. Thus further monitoring of reduced levels of the stations may be continued till all the stations show complete settlement. Except at station KJS2 in Pit 2, all the stations showed no perceptible variation indicating 
stability of the dump material. Plantation on the same dump is under progress with successful survival rate of the species such as banana, Teak, mango etc.

\section{CONCLUSION}

Two types of dumps with alternative layer of only fly ash and overburden material, and overburden and overburden mixed with fly ash (only $25 \%$ ) are found to be stable with safety factor more than 1.2 for the geometry of the dump. Beside the dump form with alternate layer of overburden and mixture of fly ash and overburden after dozing the top soil of nearly $2 \mathrm{~m}$ thick at the top, the slope also found stable with safety factor 1.78 for the above geometry. Toe walls and peripherals drains may be required after observation of the dump slope during heavy rainfall. Field measurements conducted using total station monitoring system in a typical coal mine for the first experimental trial in India with admixture for fly ash and Overburden material indicated stability of dumps over oneyear period and also unwrapped the scope of new areas of

\section{ACKNOWLEDGEMENT}

Thanks are due to the officers of Jindal Power Limited, Tamnar, Raigarh for providing necessary financial and logistic support for carrying out this work, and also to the National Institute of Technology, Rourkela for allowing to do this scientific study. Dr Sk. Md. Equeenuddin, Assistant Professor, presently HOD of Earth Sciences Dept and Dr. Sarat Kumar Das, Associate Professor of Civil Engg Dept of NIT, Rourkela helped in conducting laboratory tests and analysis of data in the above project.

\section{REFERENCES}

[1] S. K. Dhadse and L. J. Bhagia, "Fly ash characterization and utilization and government initiatives in India-a review," Journal of Scientific and Industrial Research, vol. 67, pp. 11-18, 2008.

[2] A. K. Mathur, "Ash utilisation in NTPC," In: Proceedings of the workshop on fly ash utilisation: Issues and strategies,. pp. 41-5, 2000.

[3] M. Saxena and P. Asokan, "Rehabilitation of backfill area using fly ash with suitable plant life at abandoned Gorbi mine, Northern Coal Field, Singrauli, India," Report, Regional Research Laboratory, Bhopal and CLI Coal Handling Co. Pvt. Ltd., New Delhi, India, 2000.

[4] B. Prasad and K. K. Mondal, "Leaching characteristics of fluoride from coal ash," Asian Journal of Water, Environment and Pollution, vol. 4, no. 2, pp. 17-21, 2007.

[5] E. Steiakakis, K. Kavouridis and D. Monopolis, "Large scale failure of the external waste dump at the south field lignite mine, Northern Greece," Engineering Geology, Vol. 104, pp. 269-279, 2009.

[6] Singam Jayanthu, "Field monitoring of stability of dump with $25 \%$ fly ash and $75 \%$ overburden materials related to JPOCCM mine, JPL," unpublished report of investigations, 59p, 2013.

[7] Jayanthu S et al, "Stability of fly ash and overbuden material as back filling in opencast mines - a case study," Proceedings of International conference on chemical, civil and environment engineering (ICCEE'2012) that will take place on March 24-25, 2012 in Dubai (UAE), 2012.

[8] Singam Jayanthu, and Simantini Behera, "Field monitoring of stability of dump with $25 \%$ fly ash and $75 \%$ overburden materials related to JPOCCM MINE, JPL," unpublished report, 2013 application of research introducing wireless sensor Networks for evaluation of slope stability. Dump with alternative layer of overburden and overburden mixed with fly ash (only $25 \%$ ) are found to be stable with safety factor more than 1.2 for total height of the dump, Number of decks: Height of individual deck, and slope of each deck as $120 \mathrm{~m}, 4,: 30 \mathrm{~m}$, and $32^{\circ}$, respectively. Beside the dump form with alternate layer of overburden and mixture of fly ash and overburden after dozing the top soil of nearly $2 \mathrm{~m}$ thick at the top, the slope also found stable with safety factor 1.78 for the above geometry. Displacement pattern of the monitoring stations during one-year period indicated no significant displacement in the Overburden dumps with fly ash ensuring stability of the dump near majority of the stations. Wireless Network system along with Time Domain Reflectometry (TDR) is also recommended, and attempts are being made for online and real-time monitoring of stability of slope in other opencast mines as sponsored by the Ministry of Mines, Government of India. 